\title{
Recent Morphodynamics of Alpine Lakes in Southern Carpathian Mountains using High-Resolution Optical Imagery
}

\author{
Marius Necsoiu ${ }^{1}$, Marcel Mîndrescu ${ }^{2}$, Alexandru Onaca ${ }^{3}$, Sarah Wigginton ${ }^{1}$
}

\author{
${ }^{1}$ Southwest Research Institute ${ }^{\circledR}$, Geosciences and Engineering Division, 6220 Culebra Road, \\ San Antonio, Texas, United States \\ 2 University of Suceava, Universităţii 13, RO 720229, Suceava, Romania \\ ${ }^{3}$ West University of Timişoara, Department of Geography, Str. V. Pârvan 4, Timișoara , \\ Romania \\ E-mail: mnecsoiu@swri.org
}

\section{Abstract}

This study reveals for the first time the surface area evolution of glacial lakes in the Romanian Carpathians over 47 years. The research also advances our understanding in the potential of satellite-based remote sensing techniques to monitor geomorphologic evolution of 27 rock basins turned into glacial lakes in the Retezat Mountains, Southern Romanian Carpathians. These mountains host most of the glacial lakes in Romania, including both the widest and deepest glacial lakes.

Using high-precision orthorectification and co-registration techniques, the surface area extension and reduction of 27 shallow water bodies ranging in size from 0.10 to 9.14 ha was analyzed over two time intervals (1968-2007 and 2007-2014). The total surface area increased only by $1 \%$ between 1968 and 2014, with over half of the growth occurring during the last 7 years of the study period.

Analysis of the surface area extension and reduction revealed that catchment aspect, catchment size, lake elevation, landcover, topography, and lake depth are the main environmental factors controlling the present state of the glacial lakes in the central part of the Retezat Mountains. The results suggest that the different behavior of glacial lakes within the north-facing valleys compared with the evolution of the lakes settled in southern exposed valleys is mainly due to climatic and geomorphologic particularities of the opposing slopes. On the northern side the lakes are slowly decreasing due to more intense geomorphologic activity of both the erosivity of precipitations and periglacial processes (e.g., gelifraction, mass wasting, and permafrost degradation). High altitude lakes generally are increasing because of the longer duration of the ice cover and the smaller amounts of sediment yielded 
by the nature of the soil (or lack thereof) and vegetation cover in the alpine area. Lakes with small catchments show the highest variability, displaying significant changes, whereas shallow lakes are the most prone to horizontal and vertical silting. These controls, which regulate changes in lake basin sizes, provide baseline information on current trends in the evolution of Romanian Carpathian alpine lakes. The methodology applied here could be widely applicable to other similar environments, with widespread implications for understanding the global effects of climate change on alpine lakes.

Keywords: Glacial Lakes, Carpathian Mountains, Multi-Temporal Image Analysis, Correlation Analysis, Optical Satellite Data, Corona

\section{Introduction}

Glacial rock basins, along with cirques and glacial valleys, are among the longest-lasting and most relevant traces of glaciation in the Romanian Carpathians, despite the fact that this area was glaciated solely during the Late Pleistocene (Urdea, 2000; Mîndrescu, 2006). Postdeglaciation, these rock basins turned into lakes, which occasionally evolved into peat bogs or were completely silted. Around 270 glacial lakes (including glacial peat bogs and peat bogs with pool) are estimated to exist in the Romanian Carpathians (Mîndrescu et al., 2015); they are spread unevenly with the largest share $(81 \%)$ located in the Southern Carpathians. Many of these lakes are of scientific interest, acting as sensitive and accurate climatic repositories (storing climatic and other types of data in their sediments); albeit typically, they have smaller surface areas and depths than other glacial lakes elsewhere in Europe.

The study of the origin and morphometric characteristics of alpine lakes in the Romanian Carpathians was started at the beginning of the 1900s by de Martonne and MunteanuMurgoci (1900); de Martonne (1906-1907), Loczy (1904) and Phlepps (1914). Based on the bathymetric measurements and geomorphologic observations, they assigned the glacial origin of several lakes in the Southern Carpathians. The mapping of glacial lakes was continued by Năstase (1960), Trufaș (1961; 1963) and Iancu (1961), whereas the first inventory of the glacial lakes in the Romanian Carpathians was made by Pișota (1971). To date, his work remains unparalleled in terms of scale and thoroughness, despite the upgrade of field research techniques. Pisota used the plumb line and a theodolite to perform precise measurements necessary for bathymetric sketches and lake perimeter surveys. However, the sketches he produced have no coordinates, thus making it difficult to conduct any comparative analyses. Later on, Decei (1981) published data and maps of few glacial lakes from Romania. He used similar methods, and it is likely that on occasion he based his research on information from 
his predecessor. More recently, Vespremeanu-Stroe et al., (2008) presented new and more precise data regarding the morphologic and morphometric characteristics of 13 glacial lakes in the Southern Carpathians. Their study was the first that noted some inaccuracies in the measurements made by Pișota.

The aim of our study is to evaluate the present state of the glacial lakes in the central part of the Retezat Mountains by analyzing the rates of change in surface area of 27 glacial lakes over the last half century. This study aims to assess the impact of environmental variables (climate, land cover, geomorphology and hydrology) on the dynamic of glacial lakes. It is the first study that uses very high-resolution imagery and high precision remote sensing techniques to quantify subtle lake morphologic changes that are diagnostic of the current geomorphological and climatic dynamics in this mountainous environment. This is of direct interest because most of the studies in the Carpathian-Balkan area focused on relatively early (Late Glacial and Early Holocene) environmental changes (Feurdean et al., 2014). Nevertheless, interest has increased recently in the reconstruction of more human-driven impacts on the environment and events focused over the last decades (e.g., post industrial revolution and following political change from the mid-1940s and the late 1980s) (Hutchinson et al., 2015).

\section{Site Description}

The Carpathian Mountain chain of central-eastern Europe is the largest mountain range by area in Europe. The highest peaks only reach $2500 \mathrm{~m}$, an elevation not high enough to host present-day glaciers. However, during the glacial phases of the Late Pleistocene, these peaks supported small glaciers that did not reach the foreland (Urdea et al., 2011). Although the glacial advance was less extensive in the Carpathians than in the Alps, mainly due to a more continental climate and lower altitudes (Reuther et al., 2007), glaciers descended 1000-1200 m above sea level (a.s.l.) in the highest mountain units of the Southern Carpathians (e.g., Făgăraș, Retezat, Parâng) (Urdea, 2004).

Our investigations focused on the Retezat Mountains, located in the western part of the Southern Carpathians $\left(45^{\circ} 20^{\prime} \mathrm{N}, 2^{\circ} 23^{\prime}\right.$ E) (Figure 1). The predominant lithology here consists of granodiorites. In the central sector, the subject of this study, the altitudes above $2000 \mathrm{~m}$ a.s.l. cover more than $56 \mathrm{~km}^{2}$, with several peaks approaching or exceeding $2500 \mathrm{~m}$ a.s.1. (Peleaga 2509 m a.s.1., Păpușa 2504 m a.s.1., and Retezat 2482 m a.s.1.). The Retezat landscape was shaped by Pleistocene glaciers, showing a typical alpine morphology with glacial cirques and troughs (Figure 2). In this range, 84 glacial cirques were counted and 
mapped from a total of 631 over the entire length of the Romanian Carpathians (Mîndrescu et al., 2010).

Taking the area above $1800 \mathrm{~m}$ as being the most exposed to glaciation, Făgăraș (with 238 $\mathrm{km}^{2}$ ) and the Retezat Mountains (with $116 \mathrm{~km}^{2}$ ) are in the main two places in the Romanian Carpathians (Mîndrescu et al., 2010). The snowline in the Retezat Mountains was lower during glaciation, producing longer glaciers and more complex cirques: cirque-in-cirque (i.e., inner and outer cirques). These landforms are common in the Southern Carpathians, with 35 outer and 24 inner cirques in Făgăraș and 15 outer and 24 inner cirques in Retezat (Mîndrescu and Evans, 2014). The Retezat Mountains also were able to support glaciers on south- or west-facing slopes (Urdea, 2000). Most of the high-grade cirques within the Romanian Carpathians are on the Retezat and Parâng ranges, with 17 and 12 classic cirques, respectively. Glaciation in the Retezat range had a larger impact and was more azimuthally symmetrical than the remainder of the Romanian Carpathians because this range receives more precipitation than ranges farther east.

Almost a quarter (24\%) of the 261 lakes and peat bogs mapped in the Romanian Carpathians are found in the granodiorite area of the Retezat Mountains. These 62 glacial lakes are distributed between $1718 \mathrm{~m}$ and $2210 \mathrm{~m}$ a.s.l., with an average of $2050 \mathrm{~m}$. Overall, lake surface areas range from 0.05 to 9 ha, with $77 \%$ of the lakes having surface areas less than 1 ha. Most glacial lakes also are rather shallow, with a mean lake depth of approximately $4 \mathrm{~m}$ and a maximum lake depth less than $5 \mathrm{~m}$ in $80 \%$ of the lakes. The total area of alpine lakes in the Retezat Mountains amounts to 62.24 ha, which is the largest area occupied by glacial lakes per mountain range in the Romanian Carpathians. Alpine lake catchments from Retezat average 65 ha, ranging from 1 to 200 ha. Glacial lakes occupy cirque floors to extremely variable extents (from as little as $0.22 \%$ to $68 \%$ ); however, on average, $12.30 \%$ of cirque floors are occupied by lakes. The relief (i.e. the difference in elevation between the highest and lowest points within lake catchments) averages $330 \mathrm{~m}$.

This study includes 27 glacier lakes within the central area of the Retezat Mountains (Figure 3). The timber line is situated at 1700-1800 $\mathrm{m}$ a.s.l., with higher altitudes occupied by alpine meadows and subalpine shrubs. The average lake area (peat bogs excluded) is 0.6 ha and the average depth is $2.6 \mathrm{~m}$; the largest glacial lake is Bucura ( 10 ha) and the deepest is Zănoaga ( 29 m) (Pişota, 1971). The average elevation for the glacier lakes in this study is $1980 \mathrm{~m}$ a.s.l.

The length of cored sediments collected from Retezat lacustrine and peat bog sites ranges between 3.28 and $7.62 \mathrm{~m}$, with the longest core extracted from Lia lake, and the ages of 
investigated sites vary between 14.2 and 15.75 ka (Mîndrescu et al., 2015). The range of sediment ages largely covers the post-glacial and interglacial periods following the Last Glacial Maximum. Thus, the results of limnological and paleo-limnological researches in the Retezat are of great importance to reveal the paleogeography of the Carpathian Mountains. The Retezat Mountains are predominantly under the influence of western air masses. In the alpine domain, the mean annual precipitation varies between 900 and $1400 \mathrm{~mm}$, with the highest precipitation occurring in the summer. Above $1800 \mathrm{~m}$, precipitation occurs primarily as snow between October and May. The $0^{\circ} \mathrm{C}$ isotherm lies between 2050 and $2100 \mathrm{~m}$, and the mean annual air temperature is $-2.5^{\circ} \mathrm{C}$ at $2500 \mathrm{~m}$ (Voiculescu, 2000). The mean annual air temperature and precipitation from 1960 to 2010 are presented in Figure 4, showing a distinct evolution over time. At high elevation the dominant winds come from the west and north. Winds from the north prevail $(18 \%$ and $21 \%$ of the year) at the Tarcu $(2180 \mathrm{~m}$,

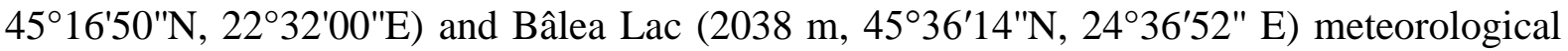
stations, whereas western winds predominate (21\% of the year) at Vârful Omu (Bogdan, 2008). On the highest peaks, $20 \%$ of the yearly winds have intensity higher than $10 \mathrm{~m} / \mathrm{s}$ (Bogdan, 2008).

\section{Data and Methods}

The remote sensing analysis (Necsoiu et al., under review) used a complementary set of optical satellite imagery (Table 1), consisting of one stereo panchromatic dataset acquired by the Corona KH-4B reconnaissance mission, a SPOT 5 satellite image, and a set of Pleiades stereopair images. The Pleiades stereopair was acquired synchronous with the field work and was used to derive a 4-m resolution digital surface model (DEM), which was essential for orthorectification and coregistration of the images.

\subsection{DEM}

Preliminary work revealed that the quality of the available public DEMs generated was too coarse to generate coregistered images to capture the dynamics of the investigated alpine lakes. Therefore, two field surveys were conducted at the study site during summer/fall 2014 using Trimble GEO Explorer (GEO XH) 6000 coupled with an external Trimble Tornado antenna. GPS measurements were recorded at 15 locations with field accuracies between 50$150 \mathrm{~cm}$ (vertical) and 20-150 cm (horizontal). Field GPS data was post processed using Trimble Terra Sync software and a network of fixed points located at Bucharest, Sophia, 
Budapest, and Bratislava. The post processing improved the positional accuracies to 19-65 $\mathrm{cm}$ (vertical) and 12-35 cm (horizontal).

The $0.5 \mathrm{~m}$ stereo panchromatic Pleiades dataset was acquired in the proximity of our second field survey (Necsoiu et al., under review). A DEM was produced in collaboration with Astrium having horizontal accuracy with root-mean-square error RMSE X $=0.6239 \mathrm{~m}$, RMSE Y $=0.5282 \mathrm{~m}$ with circular error CE $90=1.345 \mathrm{~m}$, and vertical accuracy of RMSE Z $=0.475 \mathrm{~m}$ with LE $90=0.781 \mathrm{~m}$ (Astrium, 2014).

\subsection{Orthorectification and Coregistration of Optical Data}

COSI-Corr (Coregistration of Optically Sensed Images and Correlation) technique (Leprince et al., 2007, Necsoiu et al., 2013) was used in the high-precision orthorectification and coregistration process. Nineteen stable tie points were selected from relatively flat regions of the DEM to anchor the 2007 SPOT 5 and 2014 Pleiades to the $2012 \mathrm{WV}-1$ satellite image. These tie points coincided with relatively stable features, such as wide (low height) boulders and small size juniper bushes. The resulting average misregistrations were less than one millimeter (e.g., $\sim 0.0008 \pm 0.15 \mathrm{~m}$ for a SPOT 5 image and $\sim 0.01 \pm 0.44 \mathrm{~m}$ for the Pleiades image).

Necsoiu et al. (under review) describes in detail the technique used in the orthorectification and co-registration of KH-4B Corona satellite data. These data, acquired in long 8.6 x 117 $\mathrm{km}$ film strips, are subject to extreme spatial distortions caused by a cross-path panoramic scanning system, and could only be processed by COSI-Corr after a preliminary segmentation. Sets of 4-6 tie points were collected between WorldView-1 and Corona images. The average misregistrations between these two datasets were, on average, on the order of a few centimeters.

\section{Results}

\subsection{Water Body Surface Areas}

The shorelines of the 27 alpine lakes were defined in each satellite image, and percent change in surface area was computed for the selected time periods (Figure 5, Table 2). With the exception of the Worldview-1 dataset, all satellite images were collected during August or September. Overall, minor changes in the lake size were detected during the 1968-2007 and 2007-2014 time periods. The total lake area increased only by 1\% between 1968 and 2014 . The growth was 1.4 times larger from 2007 to 2014 than from 1968 to 2007, specifically changing 7.9 times as rapidly during the last 7 of the 47 -year study period. 
In terms of surface area variation between 1968 and 2007, the majority of the investigated lakes $(69 \%)$ recorded small modifications (i.e., below 10\%). The largest variations (above $15 \%$ ) always correspond to an increase in lake size (e.g.: Florica, Viorica, Tăul Adânc, Valea

Rea 3, Tăul Valea Rea 6), with the largest increase of $45.61 \%$ for Tăul Adânc, corresponding to an increase of $10 \%$ per decade. All of the lakes experiencing an extension greater than $15 \%$ during the study period had surface areas smaller than 1 ha.

During the second time interval, between 2007 and 2014, although the average total surface area of the investigated lakes remained almost constant, the average rate of change of individual lakes is much larger. Thus, several small lakes decreased more than $10 \%$ (e.g., Tăul Adânc decreased .07ha [-11.84\%], Valea Rea 5 decreased 0.05 ha [-11.05\%], Valea Rea 3 decreased 0.1 ha [-18.21\%]), whereas only one large lake increased significantly (e.g., Tăul Thapului increased 0.25 ha $[+10.59 \%])$. Generally, the lakes located at the north of the main ridge decreased, whereas on the southern side of the highest peaks, the lakes seem to slightly increase. Overall, 62\% of the lakes increased in area from 1968 to 2014, with 58\% increasing from 1968 to 2007 and 50\% increasing from 2007 to 2014. The amplitude of individual changes increased slightly during the last 7 years of observations. Seventeen lakes were smaller than $1 \mathrm{ha}$, and two lakes were larger than 4 ha. A scatterplot of cumulative percent change is shown in Figure 5, as cumulative percent change since 1968 versus surface area. In summary, for both analyzed time intervals, little changes were identified over the entire study area.

\subsection{Comparison with Field Data}

Lake areas documented by Pisota (1971) and those estimated using 1968 Corona satellite imagery varied drastically (with a range of change from $-27.02 \%$ to $79.02 \%$ ) within just 3 years (Table 3.). Similar differences (with a range of change from $-22.82 \%$ to $79.02 \%$ ) were observed when compared to lake areas from 1968 with the lake surface areas measured by Decei 13 years later. By comparing the changes between 1968 and 1971, respective to 1968 and 1981, we observed that the maximum differences are insignificant (below 0.05 ha). The large ranges lead us to believe the changes are a result of differing interpretations, not of actual changes in lake water levels. The data published by Decei (1981) were obtained by employing similar methods as his predecessor; therefore, with no significant changes identified between 1971 and 1981 (Table 3). However, visible changes occurred between 1968 (satellite data) and the 1970-1980 timeframe. 
It also may be possible that differences be related to the time when field observations were collected, as they were performed in different months over several years. Challenges specific to water surface-land change satellite analysis - include the presence of emergent vegetation and shallow shorelines (cf. Riordan et al., 2006; Sannel and Brown, 2010) because affected areas produce reflection values similar to those of bare soil. Because field interpretations are more likely to include marshy and shallow areas as part of the lake, the resulting surface areas can be vastly different, like the case of Lake Florica (Figure 6). In other instances, surface area estimates were similar (Figure 7).

However, comparisons with recent field measurements by Vespremeanu-Stroe et al., (2008) (Table 4) revealed high agreements with this satellite-based interpretation. The good correspondence between the shorelines of the 6 glacial lakes determined by the satellite-based interpretations and the field measurements by Vespremeanu-Stroe et al., (2008) was determined mainly by the high accuracies of both approaches. Using GPS receivers (in the case of Bucura lake, a total station) and high resolution orthoimagery Vespremeanu-Stroe et al. (2008) mapped the shorelines to a sub meter accuracy. The similarities between our satellite-based results and the field measurements by Vespremeanu-Stroe et al., (2008) would have been greater if both analyses were performed in the same month. Significant rain events occurred in August and September 2007 between the field campaign and the acquisition of the SPOT 5 panchromatic images which could induce some modifications of the shorelines.

\subsection{Multivariate Analysis}

The relationships between the dynamics of lakes surface areas and the key variables (catchment size, lake elevation, lake depth, catchment aspect, and landcover) were evaluated in order to determine the role of each controlling factor.

\subsubsection{Catchment Size}

Lakes with small catchments (under 50 ha) generally increased in size by 8 to $28 \%$, with the exception of Tăul Ştirbului (catchment $\sim 39$ ha), which decreased by $4.4 \%$. However, the latter lake is shallow (depth $\sim 0.7 \mathrm{~m}$ ) and undergoes an evident process of restraint, both vertically and horizontally, which will likely lead to complete silting. Lakes with catchments above 80 ha have negative change percentages, whereas lakes with catchments larger than 120 ha are slightly expanding, as is the case with Ana and Bucura lakes. The most typical catchment size-percentage change relation-was documented at lakes Porţii and Tăul Agăţat, both of which had small catchments (under 4 ha) located on the southern slope at 
high elevation (above $2180 \mathrm{~m}$ ) with low energy of the terrain within the catchment (below $180 \mathrm{~m}$ ) and small-sized lacustrine surfaces (less than 0.4 ha).

\subsubsection{Lake Elevation}

The analysis of the lake population change indicates that lakes located at higher elevations commonly increased in size (e.g., Tăul Porţii, Tăul Agăţat), whereas lower altitude lakes decreased to a large extent (e.g., Galeșul, Pietricelele, Tăul Gemenele, Lia). The latter category typically has a higher elevation range within their catchments (i.e. the difference between the maximum and minimum elevations in the catchment), which enhances slope processes and colluvial sediment accumulation on the lake fringe. Factors that prevent the lakes from silting and decreasing in size at higher altitudes include the longer duration of the ice cover and the smaller amounts of sediment yielded by the nature of the soil (or lack thereof) and vegetation cover in the alpine area.

\subsubsection{Lake Depth}

Negative depth variations commonly are associated with lake surface decrease; the most typical examples are Tăul Ştirbului, Tăul Retezat, and Pietricelele lakes, where the relative abundance of sediment sources in the catchment results in higher sedimentation rates and faster-paced lake silting. Moreover, as a lake becomes shallower, the lateral input of alluvium is no longer retrieved and transferred by waves and streams, thus accumulating on the lake fringe and leading to lake restraining. The efficiency of this process is considerably higher for lakes with shallow shorelines.

\subsubsection{Catchment Aspect/Exposure}

The strongest correlation found was between the areal change percentage and lake catchment aspect. In conclusion, the majority of lake catchments located on the northern and western slopes (i.e., Tăul Ştirbului, Tăul Retezat, Galeșul, Pietricelele, Negru, Tăul Gemenele, Tăul Judele) are decreasing in size, whereas lakes with southern-facing catchments are expanding. The only two exceptions from the former category are Lakes Tăul Valea Rea and Tăul Stevia, where the increase is likely an effect of the small size and high elevation of the catchments.

\subsubsection{Landcover}

The landcover analysis of every lake drainage basin revealed that approximately $5 \%$ of the investigated terrain is covered by subalpine shrubs, $20.5 \%$ by alpine grasslands, $0.5 \%$ by 
water bodies, and the rest corresponds to unconsolidated debris (around 60.1\%) and bedrock (13.9\%). The predominant subalpine shrubs consist of Pinus Mugo. Except for Gemenele, Lia and Tău Negru lakes drainage area, the subalpine vegetation represents less than $10 \%$ from the surface of individual catchments. The scree slopes prevail in the majority of the cases covering, in some drainage basins, more than $80-90 \%$ of the surface (Valea Rea 2, Valea Rea 3, Zanogutele Galeșului 1). Overall, the alpine grassland vegetation occupies less than $50 \%$ of the investigated catchments.

When comparing the landcover change characteristics of the lake drainage basins we noticed that for the ones experiencing an increased area, the surface occupied by subalpine shrubs was $2 \%$ larger. In the case of the decreasing lake drainage basins, the alpine grasslands occupied $7.5 \%$ less surface, and the scree slopes covered $6 \%$ more.

The analysis also revealed differences in landcover characteristics between the drainage basins of the northern-facing and the southern-facing valleys. Specifically, the slopes covered by alpine grasslands have a larger extent in southern drainage basins (32\% S versus $9 \% \mathrm{~N})$, whereas the slopes covered by debris prevail mostly on northern catchments $(70 \% \mathrm{~N}$ versus $48 \% \mathrm{~S}$ ).

\section{Discussion and Conclusions}

The analysis of the surface area extension and reduction of 27 alpine lakes over 47 years, identified significant dependencies between the lake size behavior and several key variables: catchment size and aspect, lake elevation, lake depth, and land cover. The best correlation observed was between lake size and the catchment aspect, marking a clear differentiation between the recent dynamic of the glacial lakes on the two main slopes (north and south) of the Retezat Mountains. Negru, Gemenele, Galeșul and Ştirbu lakes are the largest investigated lakes on northern slopes and are decreasing, whereas the corresponding lakes within the south-facing cirques: Ana, Bucura, Peleaga, and Ţapu are increasing. Based on these findings, it appears that the intensity of the geomorphological processes is mainly controlled by the catchment aspect, which is significantly influenced by climatic particularities.

In relation to landform elevation and the exposure of mountain ranges to advective maritime and continental air masses, significant variations (100-200 cm) were documented in the distribution of precipitation on west- and north-facing slopes when compared to their eastand south-facing counterparts (Bogdan et al., 1983). The Retezat Mountains are a major orographic barrier for humid western air masses (west, northwest, and southwest); therefore, 
the differing exposure of glacial lake catchments (e.g., exposed to or sheltered from the west and north-west) is particularly relevant for soil erosion and colluvial sediment accumulation. Despite that more than half of the surface of the lake catchments is covered by coarse debris, the erosivity of precipitations is probably much higher on the northern slopes, leading to increasing sediment deposition on the lake banks and ultimately to a decrease in lake size.

The analysis of land cover characteristics revealed that the north-facing cirques contain considerably more debris than the ones facing south. The higher supplies of debris are the result of a more efficient frost weathering in topography with a low radiation budget (Humlum, 1998). Thus, the amplitude of the gelifraction and frost induced processes is likely to be greater on the northern slopes, leading to more intense periglacial processes (e.g., rockfalls, rock avalanches, frost creep, gelifluction) than on the southern slopes.

In high mountain environments, the instability of rock walls is controlled not only by the freeze-thaw action which induces frost shattering but also by the warming and thawing of permafrost in regions with perennial frozen rock walls (Gruber et al., 2004). Based on recent measured negative mean annual rock surface temperatures, it is assumed that permafrost is probable to occur in rockwalls above 2200-2400 m on northern slopes in the Southern Carpathians (Onaca et al., 2013; Popescu et al., 2015). The occurrence of fresh deposits in the upper part of the north-facing rock glaciers (e.g., Pietricelele, Valea Rea, Galeșul, or Ştirbu) could be the result of the recent slope destabilization due to degradation of rock wall permafrost. Based on the distribution and size of periglacial sediment storage specific landforms, as revealed by Urdea (2000) and more recent field observations, we assume that the sediment flux related to current periglacial processes plays a more important role within the northern exposed valleys. Our field observations support the assumption that periglacial processes contribute to the reduction of the surface of glacial lakes, since in many cases (e.g., Ştevia, Știrbu, Pietricelele, Agăţat) the shorelines are partially represented by coarse debris deposits.

Another important factor controlling the water balance of the alpine lakes seems to be the permafrost occurrence, recently documented in several rock glaciers by geophysical and thermal measurements (Vespremeanu et al., 2012; Onaca, 2013; Onaca et al., 2013, 2015). In some cases, springs are seeping from the base of the rock glacier fronts fueling the nearby glacial lakes (e.g., Galeșul, Tăul Valea Rea, Valea Rea 4, Pietricelele), but sub-surface flow originating from rock glaciers contribute also to the water balance of the alpine lakes (Clark, 1988). It is well known that rock glaciers are important water storages in mountainous environments (Haeberli, 1985), whereas the melting processes of the frozen ground play an 
important role in the alpine rivers discharge during summer months (Schrot, 1996). Previous contributions revealed that during the Little Ice Age (LIA), rock glaciers located mainly on the northern flanks of the Southern Carpathians were reactivated as a result of permafrost aggradation (Onaca et al., under review). After the LIA, air temperature rising in the Southern Carpathians (Tanţău et al., 2011) led to permafrost degradation by increasing the thickness of the active layer (Onaca et al., 2013) and in the long term, a decrease in flow discharge occurred, especially in the case of north-facing springs. We asssume that on the southern slopes the disturbances in the local hydrological system occurred at the end of the Pleistocene, when most of the rock glaciers on the southern slope became relict (except Judele and Berbecilor). We assume that only within small catchments, or where the lakes are very close to rock glaciers (e.g., Știrbu, Valea Rea 4, Pietricelele, Galeșul) the contribution of permafrost melting to the lakes water balance is significant, whereas in case of very large catchements (e.g. Bucura, Ana) this variable is negligible.

Furthermore, Vespremeanu-Stroe et al. (2008) showed that on the shorelines of Ana and Bucura due to repeated freezing and thawing episodes, patterned grounds morphology occurred as a result of particle-size sorting, upfreezing of stones, frost creep, and gelifluction. In the long-term these small-scale processes also could play an important role in the modification of the shorelines. The thermal measurements performed in the case of Ana glacial lake for one season (e.g., 2010-2011) revealed that the beach of the lake and the shallow waters near the shorelines are completely frozen for approximately 6 months, between the end of November and the end of May (unpublished data). Effective freeze-thaw cycles affect the shorelines ground surface between October-November and May-June at the Ana site. The north-facing lakes receive less sunlight and remain frozen for a longer interval, being less affected by wave erosion and sediment redistribution.

The importance of wave erosion was pointed out for Ana and Bucura, where wave-cut platforms and wave-built terraces were described previously (Vespremeanu-Stroe et al., 2008). These hydrologic processes were not reported for the large lakes on the northern slopes, such as Galeșul, where bathimetric measurements also were performed. However, the importance of waves and currents is restricted only to large and deep lakes, whereas the small and shallow lakes seems unable to remove the input of lateral sediment that is progressively stored at the lake fringe. The observations performed in the field support this assumption for lakes characterized by shallow shorelines, such as Pietricelele, Florica and Gemenele, and where the extremely irregular contour of the lakes support the observation that the input of 
debris was not redistributed by waves and currents. In the foreseeable future, the lateral restraining of small lakes with shallow shorelines will likely result in complete silting.

The multivariate analysis also showed that at high altitudes, independent of exposition, the lakes have the tendency to increase (e.g., Zănoguțele Galeșului 3,Tăul Porţii, Tăul Agățat, Ștevia), mainly as a result of the higher precipitations, longer duration of the ice cover, and the lack of topsoil in the alpine catchments. These lakes generally are settled in small cirques or have small drainage areas and their sediment flux is not as important as in the case of large catchments.

Furthermore, we found that a group of lakes are constrained by topography and exhibit visible seasonal variations in level. These are cirque floor lakes occupying a large extent or the entire cirque floor, formed as a result of glacier erosion (as opposed to moraine lakes), and inhabit basins completely surrounded by the cirque headwall and lip. Therefore, these lakes are topography-constrained and cannot exceed a certain areal size, due to the outflow that will drain excess water, but rather exhibit various level variations. This particular category includes lakes Țapul (8), Tăul Negru (10), Bucura (3), Peleaga (5) and Gemenele (12), which account for more than one third of the cirque floor area and are typically located next to the headwall. A distinct group of the surveyed lakes include those with large catchments, located in broad armchair-type glacial cirques (such as Galeșul Lake) or within glacial valleys (e.g., Lia lake). Documented changes show negative and positive variations. These are sizeable lakes in terms of surface and depth (especially related to the mean size of glacial lakes from the Romanian Carpathians) supplied by catchments ranging from 120 to 430 ha.

This particular area appears to be one of the least disturbed environments in Europe, and lake sediment investigations could provide clues regarding long-term climate and environmental variability and change. A paleo-environmental perspective on environmental issues is widely recognized as beneficial, especially when making informed predictions for future environment conditions (e.g., Schmidt and Moyer 2008).

The glacial lakes are valuable proxy indicators of former environmental conditions, since the morphometric characteristics and small-scale landforms of the lake basins represent the results of the interactions between the glacial processes and the post-glacial silting processes. Unfortunately, in most of the cases, the initial glacial morphology of the glacial basins is not known, due to thick sediment depositions within the lake basins. Recent geophysical measurements (Ardelean, 2015) revealed that in the case of Doamnei glacial lake (Făgăraș Mountains), the size and the depth of the initial glacial rock basin were much higher than 
what is considered the current depression according to bathymetric data (Pișota, 1971). This is the reason why the existing bathymetric maps of glacial lakes should be considered with caution when interpreting the glacial processes involved in the genesis of these lakes. However, specific glacial processes (glacial overdeepening and subglacial torrents erosion) and landforms (troughs, platforms and bowl-like depressions) were mentioned by Vespremeanu-Stroe et al., (2008) when interpreting the bathymetric maps of Bucura, Galeșul, Lia and Ana. In order to accurately evaluate the actual behavior of glacial lakes, the original shapes of the rock basins are extremely important; unfortunately, these data were not available for the analyzed lakes in this study.

Sediment cores ranging between 3.28 and $7.62 \mathrm{~m}$ in length were collected from the six sites (Bucura, Galeşul, Tăul dintre Brazi, Lia, Tăul Negru, and Tăul Zănoguţii), with maximum ages varying between 13.6 and $15.12 \mathrm{ky} \mathrm{BP}$. The sedimentation rates yielded by these data range from 0.21 to $0.54 \mathrm{~mm} \mathrm{yr}^{-1}$ and are a measure of vertical changes (i.e. silting) of glacial lake basins. The thickness of the sediment deposits in lake basins indicate that most lakes are silted to a large extent, exceeding $50 \%$ of the initial capacity of the basins. In regards to short-term sediment accumulation rates (SAR) in the lakes from the Retezat Mountains, the age-depth model at Tăul Negru suggests small fluctuations in the mean SAR over the period 1867-2009. The mean sedimentation rate was $0.007 \mathrm{~g} \mathrm{~cm}^{-2}$, with slightly higher values between 1880 and $1900\left(0.01 \mathrm{~g} \mathrm{~cm}^{-2}\right.$ year $\left.^{-1}\right)$ and between 1970 and $1985\left(0.009 \mathrm{~g} \mathrm{~cm}^{-2} \mathrm{year}^{-1}\right)$, respectively. For small, deep mountain lakes ( $\leq 50 \mathrm{ha}, \geq 5 \mathrm{~m}$, laketype 1321) in CentralWestern Europe, SARs were found to be lower in the 1850 period $\left(0.005-0.007 \mathrm{~g} \mathrm{~cm}^{-2}\right.$ year $\left.^{-1}\right)$ and increased modestly more recently. In many of these lakes, however, SARs have remained constant through the entire period (Rose et al., 2009). In contrast to CentralWestern European lakes, small, deep mountain lakes (e.g. Tăul Negru in the Retezat range, Lake Capra in the Făgăraş Mountains) show highest SARs $\left(0.05-0.10 \mathrm{~g} \mathrm{~cm}^{-2}\right.$ year $\left.^{-1}\right)$ in the 1850-1920 period (Hutchinson et al., 2015).

Geomorphological changes of lake basins throughout the Holocene were dependent on climatic variability; in turn, during the past 2 centuries, human presence and activity became an additional factor (e. g., shepherding, dwarf pine deforestation, tourist activities) with increasingly higher impact in the Romanian Carpathians. The recent climatological analysis in the Carpathian region suggests an increasing temperature trend, particularly during the last 3 decades, whereas wind speed decreased in every season and precipitation showed no significant trend (Spinoni et al., 2015). In the Retezat Mountains, the relatively stable behavior of the majority of investigated glacial lakes may be due to small precipitation 
variations, as the incoming water supplied by seasonal snow-melt water and rainfalls mainly control the water levels of the alpine lakes. The evolution of lake basins and their various changes were controlled by the typical conditions from the Romanian Carpathians: moderate elevation ranges, the lack of perennial ice-cover or snow, mixed geology dominated by granite/granodiorite and crystalline schists with low resilience, the continental climate, the geomorphologic processes as well as the land use in the mountain areas, which was pastoral to a large extent during the past several centuries.

\section{Acknowledgements}

This research was funded in part by the U.S. National Science Foundation (NSF) Grant \#1346687 "U.S.-Romania Collaboration: Rock Glaciers Dynamics and Permafrost Degradation Using High-Resolution Optical and Multi-Polarization SAR Imagery” led by M. Necsoiu. Special thanks to S. Rubin and K. Weber (Astrium) for assistance in acquiring Pléiades data and producing the 4-m DEM; F. Sîrbu and B. Magori (WUT) for help in collecting GPS data. Finally, we thank S. Stothoff and R. McGinnis (SwRI) for their technical and programmatic reviews, L. Neill for editorial review, and two anonymous reviewers for constructive criticisms and recommendations.

\section{References}

Ardelean, A.C., 2015. Quantifying sediment storage and determining denudation rates in Doamnei Valley, Făgăraș Mountains, PhD Thesis, West University of Timișoara, 170 pp. Astrium, 2014. DSM Spatio triangulation Report Pléiades Roumanie - Peleaga EL1, 1-7.

Bogdan, O., 2008, Carpaţii Meridionali. Clima, hazardele meteoclimatice şi impactul lor asupra turismului, Editura Universităţii „Lucian Blaga” Sibiu, 324 p.

Bogdan, O., Teodoreanu, E., Neamu, G., Erhan, E., Apăvăloaie, M., 1983. Precipitațiile atmosferice in Geografia Romaniei, Geografia Fizică (vol. I), Edit. Academiei București

Clark, M.J., 1988. Periglacial hydrology in Advances in periglacial geomorphology (editor: M. Clark), Chichester, 415-463.

Decei, P., 1981. Lacuri de munte. Drumetie si pescuit (in Romanian), Editura Sport Turism, Bucharest.

Gruber, S., Hoelzle, M., Haeberli, W., 2004. Rock-wall temperatures in the Alps : Modelling their topographic distribution and regional differences. Permafrost and Periglacial Processes, 15, 299-307. 
Feurdean, A., Perşoiu, A., Tanţău, I., Stevens, T., Magyari, E.K., Onac, B.P., Marković, S., Andrič, M., Connor, S., Fărcaș, S., Gałka, M., Gaudeny, T., Hoek, W., Kolaczek, P., Kuneš, P., Lamentowicz, M., Marinova, E., Michczynska, D.J., Perşoiu, I., Płociennik, M., Słowinski, M., Stancikaite, M., Sumegi, P., Svensson, A., Tămaș, T., Timar, A., Tonkov, S., Toth, M., Veski, S., Willis, K.J., Zernitskaya, V., 2014. Climate variability and associated vegetation response throughout Central and Eastern Europe (CEE) between 60 and 8 ka. Quaternary Science Reviews 106: 206-224.

Haeberli, W. 1985., Creep of mountain permafrost: internal structure and flow of alpine rock glaciers. Mitteilungen der Versuchsanstalt für Wasserbau, Hydrologie und Glaziologie, 139 p.

Humlum, O., 1998. The climatic significance of rock glaciers. Permafrost and Periglacial Processes 9: 375-395.

Hutchinson S.M., Akinyemi, F.O., Mîndrescu, M., Begy R., Feurdean, A., 2015. Recent sediment accumulation rates in contrasting lakes in the Carpathians (Romania): impacts of shifts in socio-economic regime. Regional Environmental Change. 10.1007/s10113015-0764-7.

Leprince S., Ayoub F., Klinger Y., and Avouac, J. P., 2007. Co-registration of optically sensed images and correlation (COSI-Corr): an operational methodology for ground deformation measurements IGARSS 2007: IEEE Int. Geosci. Remote Sens. Symp. (Barcelona).

Iancu, S., 1961. Contribuţii la cunoaşterea lacurilor alpine din Masivul Parâng, Analele Universităţii "C.I.Parhon"' București, Seria Şt. Naturii, Geologie-Geografie, X, 27, 163177

Loczy, 1904. A Retyezat tavairól, Földrajzi Közlemnyek ,XXXII, 224-233

Martonne, Emm. de, 1906-1907. Recherches sur l'évolution morphologiques des Alpes de Transylvanie (Karpates méridionales), Revue de géographie annuelle, I Paris, 286 p.

Martonne, Emm. de, Munteanu-Murgoci, G., 1900. Sondage et analyse des boues du Lac Gâlcescu. Comptes Rendues des Séances de l'Academie des Sciences Paris, 103, 932935.

Mîndrescu, M., 2006. Geomorphometry of the glacial circues in the Romanian Carpathians. PhD. Thesis. A.I.Cuza University of Iasi, 305 pp. 
Mîndrescu, M., Evans I.S., Cox, N.J., 2010. Climatic implications of cirque distribution in the Romanian Carpathians: Palaeowind directions during glacial periods. Journal of Quaternary Science, 2010, 25(6): 875-888.

Mîndrescu, M., Evans, I.S., 2014. Cirque form and development in Romania: allometry and the buzz-saw hypothesis. Geomorphology, 208:117-136.

Mîndrescu., M., Florescu, G., Gradinaru, I., Haliuc, A., 2015. Lakes, lacustrine sediments and palaeoenvironmental reconstructions in Landform Dynamics and Evolution in Romania (editors: Maria Radoane and Alfred Vespremeanu-Stroe), Springer, Switzerland (accepted).

Năstase, A., 1960. Lacurile Capra şi Căpriţa din Masivul Făgăraş, Probleme de Geografie, VII, 267-274.Necsoiu, M., Dinwiddie, C.L., Walter, G.R., Larsen, A., and Stothoff, S.A., 2013. Multi-temporal image analysis of historical aerial photographs and recent satellite imagery reveals evolution of water body surface area and polygonal terrain morphology in Kobuk Valley National Park, Alaska. Environmental Research Letters, 8(2): 025007.

Necsoiu, M., A. Onaca, S. Willington, and Urdea, P., Rock Glacier Dynamics in Southern Carpathians Mountains from High-Resolution Optical and Multi-Temporal SAR Satellite Imagery, Remote Sensing of Environment (under review).

Onaca, A. 2013. Periglacial processes and landforms from the Southern Carpathians. A geomorphological and geophisical approach. Phd. Thesis, West University of Timisoara, $237 \mathrm{pp}$.

Onaca, A., Urdea, P., Ardelean, A., 2013. Internal structure and permafrost characteristics of the rock glaciers of Southern Carpathians (Romania) assessed by geoelectrical soundings and thermal monitoring, Geografiska Annaler, Series A, Physical Geography, 249-266.

Onaca, A., Ardelean, A.C., Urdea, P., Ardelean, F., Sîrbu, F., 2015. Detection of mountain permafrost by combining conventional geophysical methods and thermal monitoring in the Retezat Mountains, Romania. Cold Regions Science and Technology, 119: 111-123.

Onaca, A., Ardelean, F., Urdea, P., Magori, B., Southern Carpathians rock glaciers: inventory, distribution and environmental controlling factors, Geomorphology (under review).

Phlepps, O., 1914. Studien an den Hochgebirgsseen auf den Nordgehäge des Fogarascher Gebirges, Festschrift zur wanderversammlung. Ärtze und Naturfoscher, Sibiu, 140-156.

Pisota, I., 1971, Lacurile glaciare din Carpatii Meridionali, Studiu hidrologic, Editura Academiei, Bucharest 
Popescu, R., Vespremeanu-Stroe, A., Onaca, A., Cruceru, N., 2015. Permafrost research in the granitic massifs of Southern Carpathians (Parâng Mountains). Zietschrift fur Geomorphologie, 59, 1, 1-20.

Reuther, A.U., Urdea, P., Geiger, C., Ivy-Ochs, S., Niller, H-P., Kubik, P.W., Heine, K., 2007. Late Pleistocene glacial chronology of the Pietrele Valley, Retezat Mountains, Southern Carpathians constrained by ${ }^{10} \mathrm{Be}$ exposure ages and pedological investigations. Quaternary International 164-165, 151-169.

Riordan, B., Verbyla, D., McGuire, A.D., 2006. Shrinking ponds in subarctic Alaska based on 1950-2002 remotely sensed images, J. Geophys. Res. 111 G04002

Rose, N.L., Cogalniceanu, D., Appleby, P.G., Bancelj, A., Camarero, L., Fernandez, P., 2009. Atmospheric contamination and ecological changes inferred from the sedimentary record of Lacul Negru in the Retezat National Park. Advanced Limnology 62:319-350.

Sannel, A.B.K., Brown, I.A., 2010. High-resolution remote sensing identification of thermokarst lake dynamics in a subarctic peat plateau complex, Can. J. Remote Sens., 36 S26-40

Schmidt, G. and Moyer, E., 2008. A new kind of scientist. Nature Reports Climate Change 2: 102- 103.

Schrott, L., 1996. Some geomorphological-hydological aspects of rock glaciers in the Andes (San Juan, Argentina). Z. Geomorphol., 104: 161-173.

Spinoni, J., Szalai, S., Szentimrey, T., Lakatos, M., Bihari, Z., Nagy, A., Nèmeth, A., Kovács, A., Mihic, D., Dacic, M., Petrovic, P., Kržič, A., Hiebl, J., Auer, I., Milkovic, J., Štepánek, P., Zahradnícek, P., Kilar, P., Limanowka, D., Pyrc, R., Cheval, S., Birsan, M.V., Dumitrescu, A., Deak, G., Matei, M., Antolovic, I., Nejedlík, P., Štastný, P., Kajaba, P., Bochnícek, O., Galo, D., Mikulová, K., Nabyvanets, Y., Skrynyk, O., Krakovska, S., Gnatiuk, N., Tolasz, R., Antofie, T., Vogt, J., 2015. Climate of the Carpathian Region in 1961-2010: Climatologies and Trends of 10 Variables. International Journal of Climatology, 35(7): 1322-1341.

Tanțău, I., Fărcaș, S., Beldean, C., Geantă, A. and Ștefănescu, L., 2011. Late Holocene paleoenvironments and human impact in Făgăraș Depression (southern Transylvania, Romania). Carpathian Journal of Earth and Environmental Sciences 6, 171-178.

Trufaş, V., 1961. Lacurile din relieful glaciar al Munţilor Şureanu, Meteorologia, hidrologia şi gospodărirea apelor, VI, 1, 22-25. 
Trufaş, V., 1963. Iezerele din Munţii Cindrel, Comunicări de Geografie, Societatea de ştiinţe naturale, secţia Geografie, II, 69-80.

Urdea, P., 2000. Munţii Retezat. Studiu geomorfologic, Edit. Academiei Române, Bucureşti, 272.

Urdea, P. 2004. The Pleistocene glaciation of the Romanian Carpathians.In Quaternary Glaciations: Extent and Chronology. Part 1: Europe, Ehlers J, Gibbard PL (eds). Elsevier: Amsterdam; 301-308.

Urdea, P., Onaca, A., Ardelean, F., Ardelean, M., 2011. New evidence on the Quaternary glaciation in the Romanian Carpathians. In: Ehlers, J., Gibbard, P.L., Hughes, P.D. (Eds.), Developments in Quaternary Science. Elsevier, Amsterdam, 305-322.

Vespremeanu-Stroe, A., Urdea, P., Tatui, F., Constantinescu, S., Preoteasa, L., Vasile, M. and Popescu, R., 2008. Date noi privind morfologia lacurilor glaciare din Carpaţii Meridionali. Revista de Geomorfologie 10:73-87.

Vespremeanu-Stroe, A., Urdea, P., Popescu, R., and Vasile, M., 2012. Rock Glacier Activity in the Retezat Mountains, Southern Carpathians, Romania. Permafrost and Periglacial Processes, 23(2): 127-137Voiculescu, M., 2000. Considerations concerning permafrost prediction in the Fagaras Massif (Southern Carpathians). Studia Geomorphologica Carpatho-Balcanica 34: 123-135.

\section{List of Figures}

Figure 1. Glacial lake distribution in the Retezat Mountains, Romania. A SRTM digital elevation model with $200 \mathrm{~m}$ contour lines was used as background. In the inset, the location of the study area is shown in yellow.

Figure 2. Series of glacial lakes on the south facing slope in the Retezat Mountains. From the foreground to the far distance: Tăul Agăţat, Florica, Viorica, Ana, Lia and Bucura (photo: M. Mîndrescu).

Figure 3. Geographical distribution of the largest 27 alpine lakes located in the central part of the Retezat Mountains. Panchromatic 2012 WorldView-1 image draped with alpine lake contour lines. The names associated with the numbers are listed in Table 2.

Figure 4. Climate data at Țarcu meteorological station over a 40-year period. (a) Mean annual air temperature data indicate this variable had a minimum in 1980 at $-1.8{ }^{\circ} \mathrm{C}$, 
following a steady increase. (b) Mean annual precipitation indicates a decrease in the precipitation regime until the mid-1990s following a steady increase.

Figure 5. Scatterplot of cumulative percent change in water body surface area since 1968 versus water body surface area. Dash lines indicate lakes located on the south of the main ridge while continuous lines indicate lakes located on the north of the main ridge.

Figure 6. Lake Florica: difference between the shape drawn from the Pisota (1971) sketches and the extent interpreted based on the Corona imagery.

Figure 7. Lake Bucura: Similarity between the shape drawn from the Pisota (1971) sketches and the extent interpreted based on the Corona imagery. 
Recent Morphodynamics of Alpine Lakes in Southern Carpathians

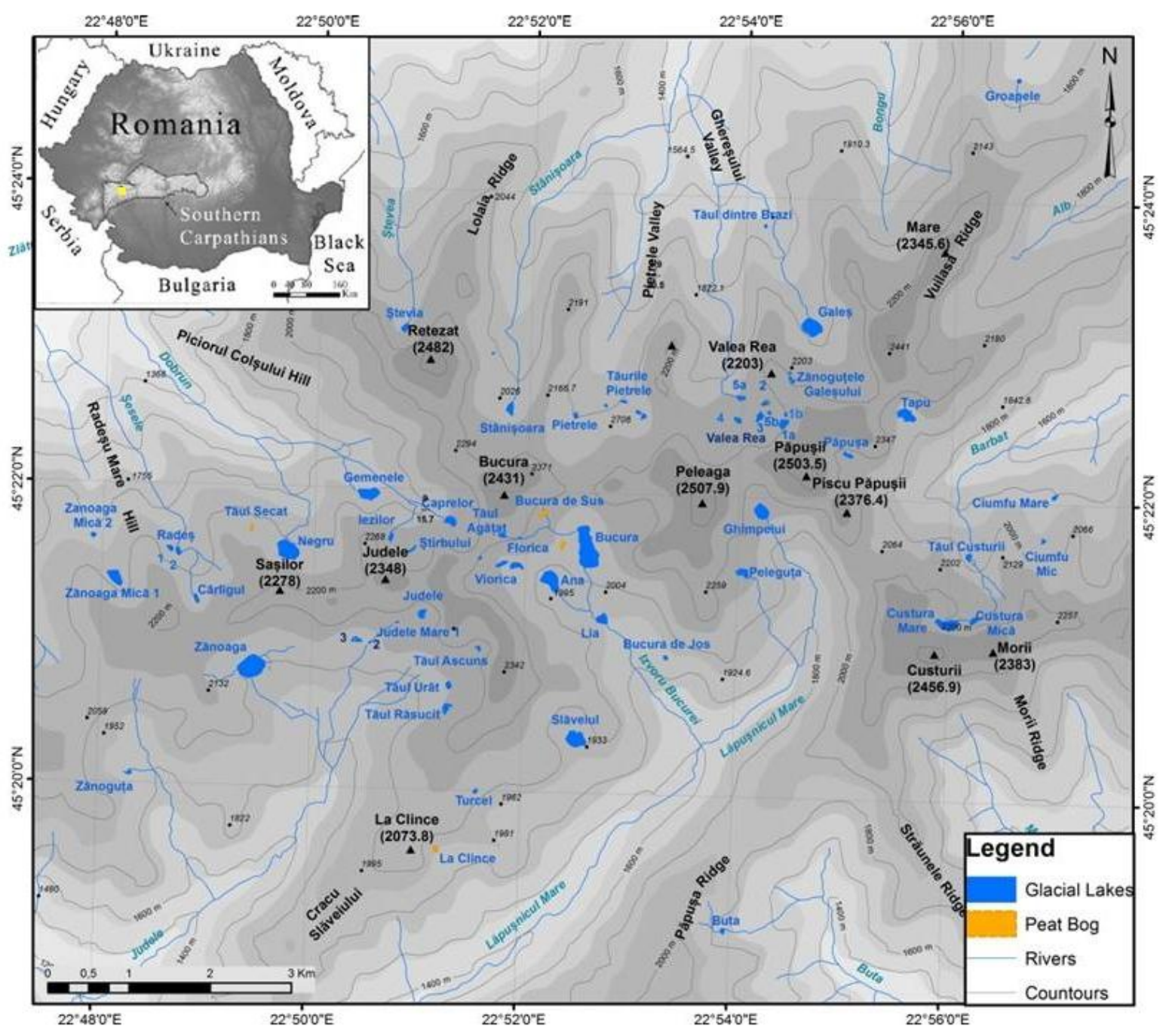


Recent Morphodynamics of Alpine Lakes in Southern Carpathians

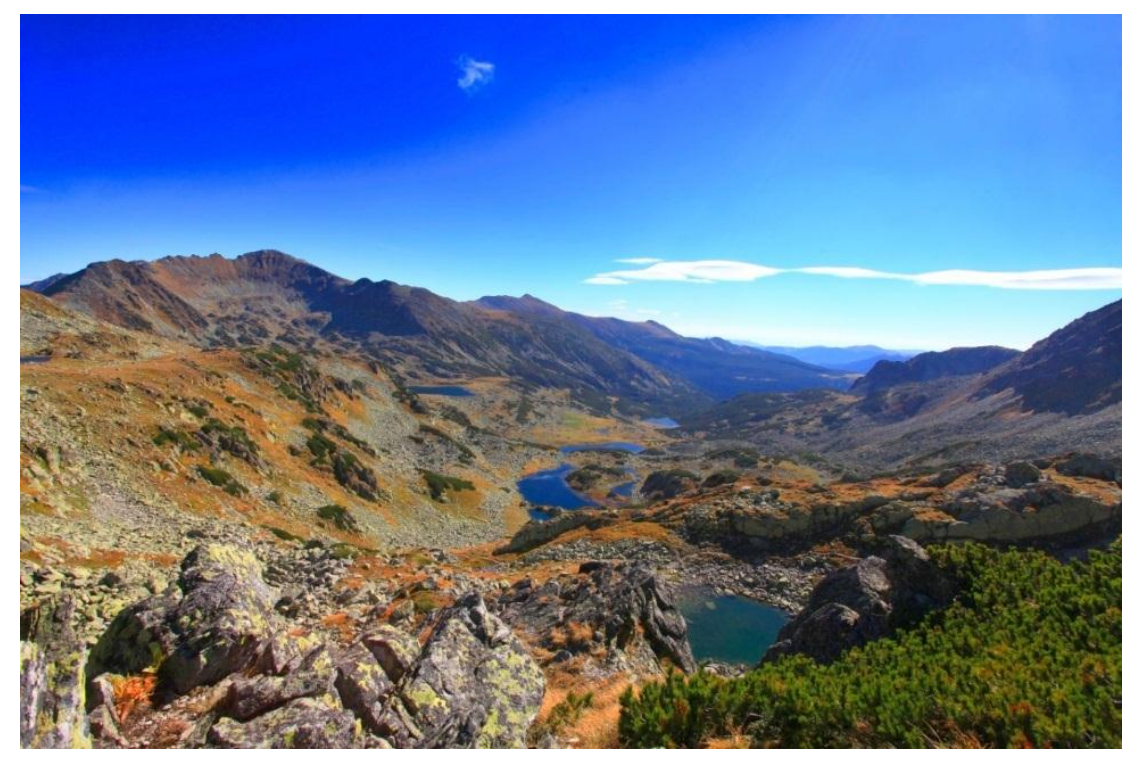




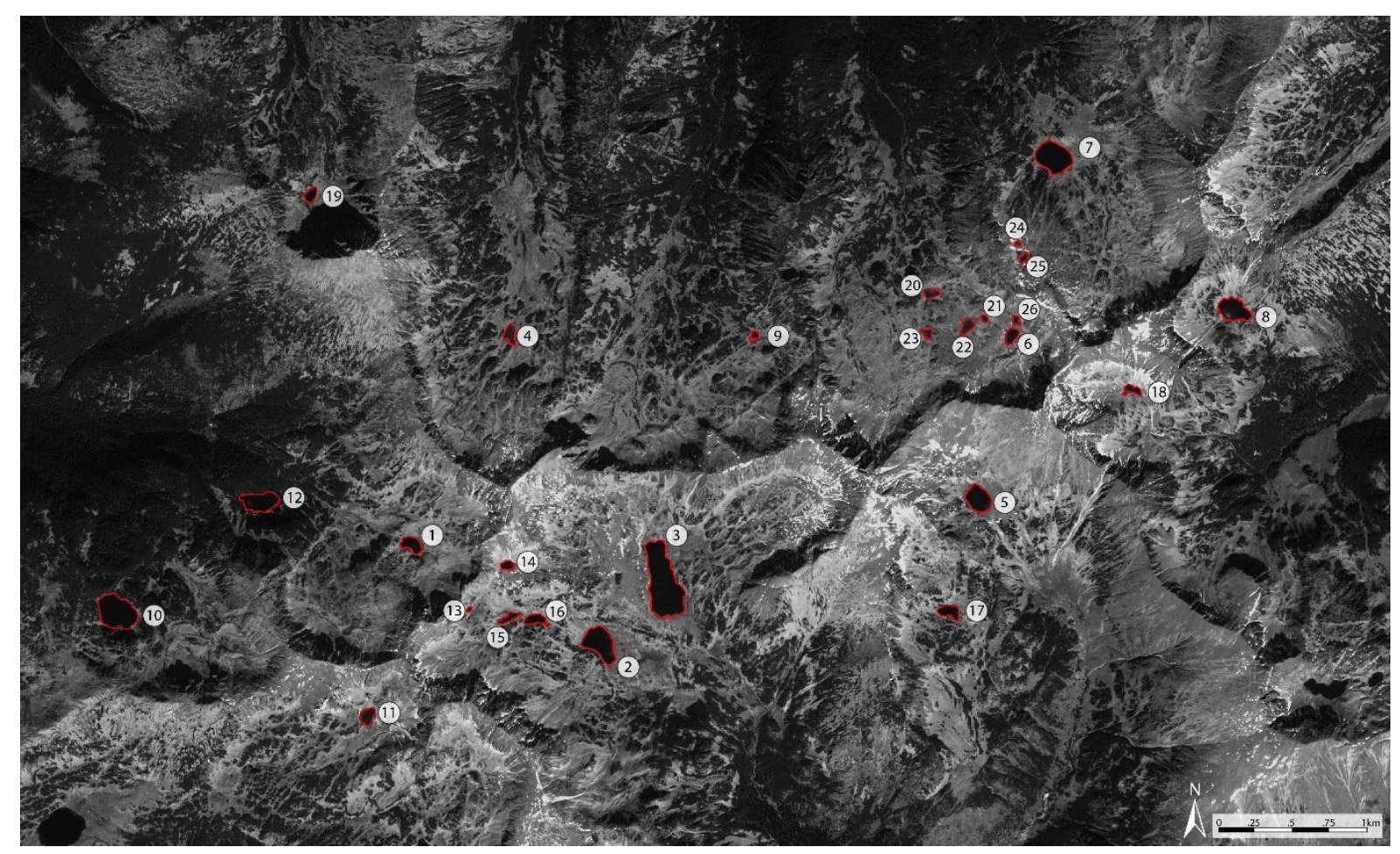


Recent Morphodynamics of Alpine Lakes in Southern Carpathians
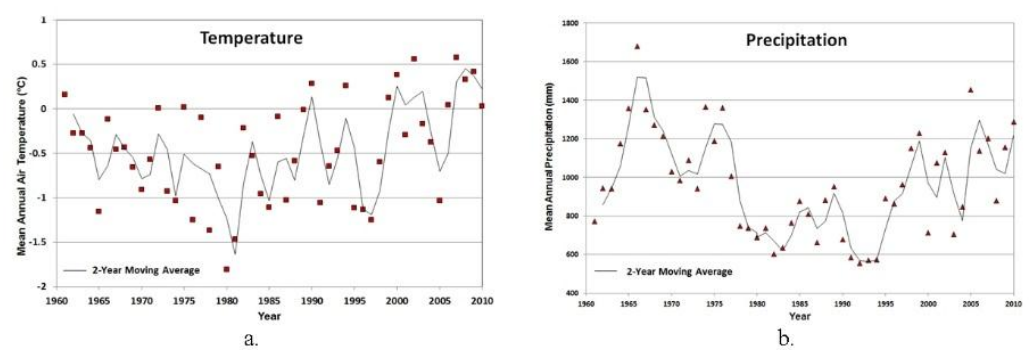
Recent Morphodynamics of Alpine Lakes in Southern Carpathians

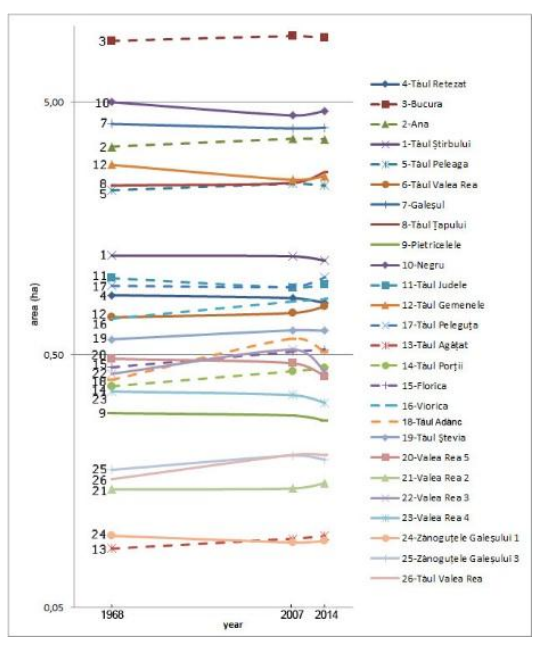




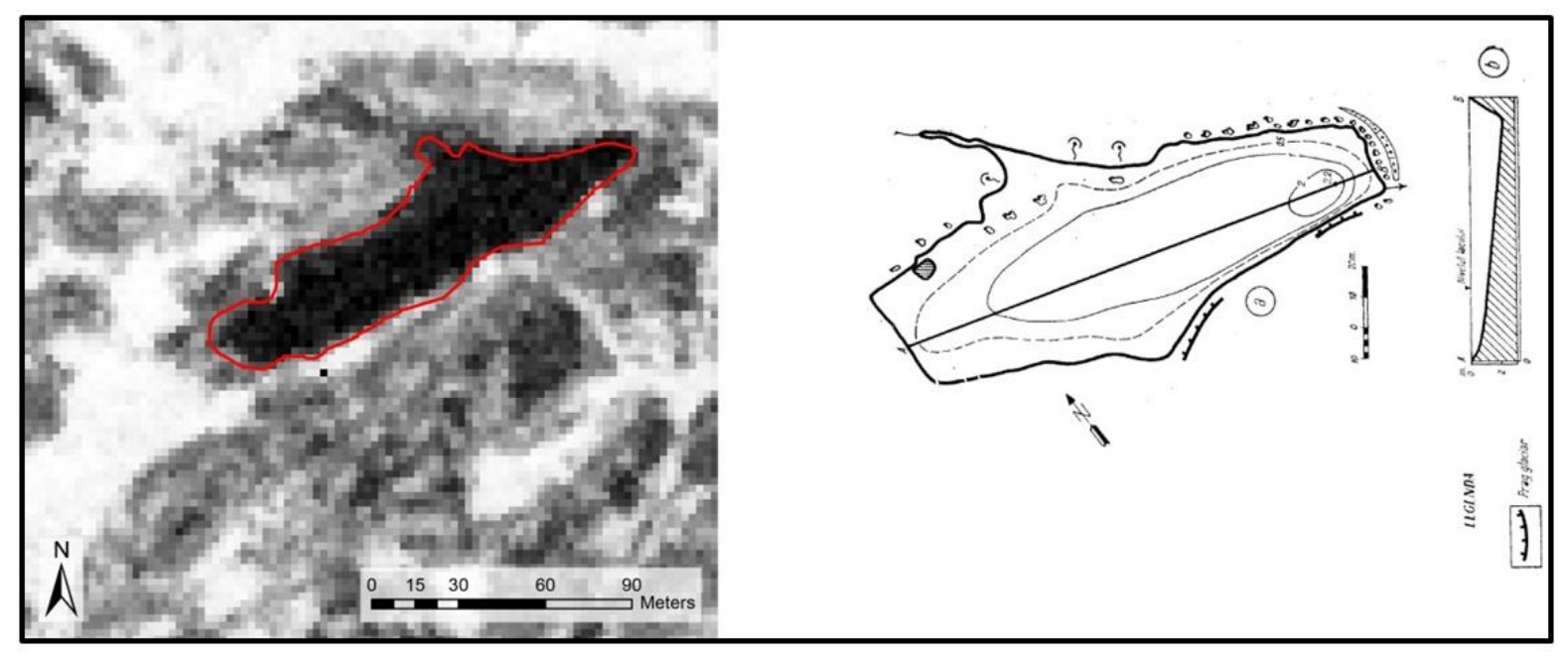


Recent Morphodynamics of Alpine Lakes in Southern Carpathians

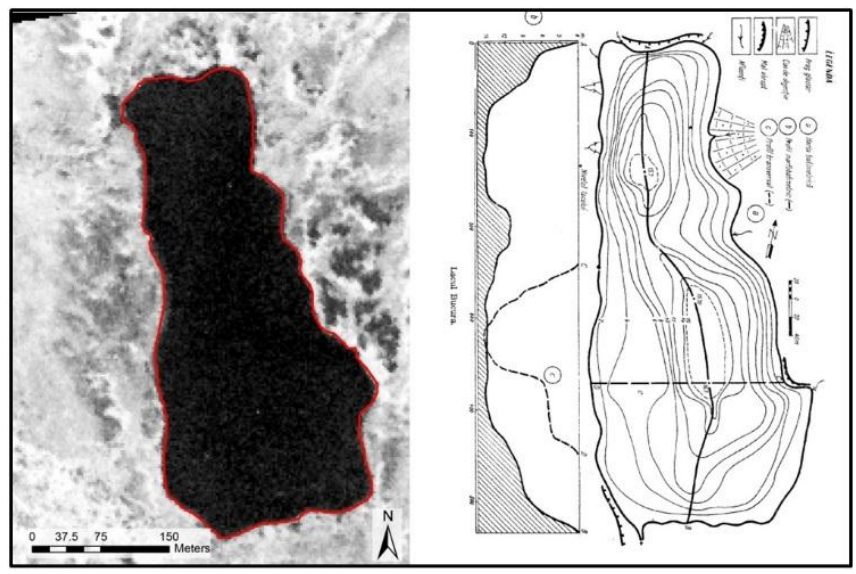




\begin{tabular}{|c|c|c|}
\hline Optical Image Dataset & Acquisition Date & $\begin{array}{l}\text { Resolution/Nadir } \\
\text { Angle }\end{array}$ \\
\hline \multicolumn{3}{|l|}{ Corona KH-4B Black \& White (B/W) } \\
\hline \multicolumn{3}{|l|}{$\begin{array}{l}\text { Stereo Panchromatic Film } \\
\text { (Mission: } 114-04 \\
\text { Camera Resolution: High } \\
\text { Film Type: } 70 \mathrm{~mm} \text { Pan } \\
\text { Focal length: } 610 \mathrm{~mm} \text { ) } \\
\text { 155A019 }\end{array}$} \\
\hline $\begin{array}{ll}\text { 1. } & 2155 \mathrm{DA} 019 \\
\text { 2. } & 2155 \mathrm{DF} 013\end{array}$ & 17 August, 1968 & $1.2 \mathrm{~m} /+/-15^{\circ}$ \\
\hline SPOT 5 Panchromatic Images & 22 September 2007 & $2.5 \mathrm{~m} / 1.80^{\circ}$ \\
\hline $\begin{array}{l}\text { WorldView-1 Panchromatic Image } \\
\text { (used only in the orthorectification and } \\
\text { co-registration process) }\end{array}$ & 20 July 2012 & $0.5 \mathrm{~m} / 20.31^{\circ}$ \\
\hline Pleiades Stereopair Images & 28 September 2014 & $0.5 \mathrm{~m} /+8.6^{\circ} /-9.6^{\circ}$ \\
\hline
\end{tabular}

*) all datasets have cloud cover less than $5 \%$. 
Table 2. Alpine lake surface areas and percent changes

\begin{tabular}{||l||ccc|ccc||}
\hline \multicolumn{1}{|c|}{ Alpine Lake } & \multicolumn{5}{c|}{ Area (ha) } & \multicolumn{3}{c||}{ \%Change } \\
\cline { 2 - 7 } & $\mathbf{1 9 6 8}$ & $\mathbf{2 0 0 7}$ & $\mathbf{2 0 1 4}$ & $\mathbf{2 0 0 7 / 1 9 6 8}$ & $\mathbf{2 0 1 4 / 2 0 0 7}$ & $\mathbf{2 0 1 4 / 1 9 6 8}$ \\
\hline 1- Tăul Ştirbului & 1.24 & 1.23 & 1.18 & $-0.57 \%$ & $-3.82 \%$ & $-4.37 \%$ \\
2- Ana & 3.34 & 3.59 & 3.58 & $7.30 \%$ & $-0.25 \%$ & $7.03 \%$ \\
3- Bucura & 8.76 & 9.14 & 8.99 & $4.43 \%$ & $-1.72 \%$ & $2.64 \%$ \\
4- Tăul Retezat & 0.86 & 0.84 & 0.80 & $-2.68 \%$ & $-4.32 \%$ & $-6.88 \%$ \\
5- Tăul Peleaga & 2.24 & 2.38 & 2.34 & $6.11 \%$ & $-1.64 \%$ & $4.37 \%$ \\
6- Tăul Valea Rea & 0.70 & 0.73 & 0.78 & $4.06 \%$ & $6.16 \%$ & $10.47 \%$ \\
7- Galeșul & 4.11 & 3.94 & 3.97 & $-3.92 \%$ & $0.71 \%$ & $-3.24 \%$ \\
8- Tăul Tapului & 2.34 & 2.40 & 2.65 & $2.39 \%$ & $10.59 \%$ & $13.23 \%$ \\
9- Pietricelele & 0.29 & 0.29 & 0.28 & $-2.17 \%$ & $-4.51 \%$ & $-6.58 \%$ \\
10- Negrub & 5.01 & 4.44 & 4.63 & $-11.44 \%$ & $4.42 \%$ & $-7.52 \%$ \\
11- Tăul Judele & 1.01 & 0.92 & 0.95 & $-8.33 \%$ & $2.71 \%$ & $-5.85 \%$ \\
12- Tăul Gemenele & 2.83 & 2.47 & 2.55 & $-12.73 \%$ & $3.36 \%$ & $-9.79 \%$ \\
13- Tăul Agăţat & 0.09 & 0.09 & 0.10 & $9.49 \%$ & $2.40 \%$ & $12.12 \%$ \\
14- Tăul Porţiif & 0.38 & 0.43 & 0.44 & $14.62 \%$ & $2.90 \%$ & $17.94 \%$ \\
15- Florica & 0.45 & 0.52 & 0.53 & $15.24 \%$ & $2.18 \%$ & $17.76 \%$ \\
16- Viorica & 0.70 & 0.81 & 0.83 & $16.88 \%$ & $2.14 \%$ & $19.38 \%$ \\
17- Tăul Peleguţad & 0.94 & 0.93 & 1.02 & $-0.80 \%$ & $8.99 \%$ & $8.12 \%$ \\
18- Tăul Adânc & 0.40 & 0.58 & 0.51 & $45.61 \%$ & $-11.84 \%$ & $28.37 \%$ \\
19- Tăul Steviae & 0.58 & 0.63 & 0.62 & $8.45 \%$ & $-0.42 \%$ & $8.00 \%$ \\
20- Valea Rea 5 & 0.48 & 0.46 & 0.41 & $-4.01 \%$ & $-11.05 \%$ & $-14.62 \%$ \\
21- Valea Rea 2 & 0.15 & 0.15 & 0.16 & $0.85 \%$ & $5.06 \%$ & $5.96 \%$ \\
22- Valea Rea 3 & 0.42 & 0.53 & 0.43 & $24.63 \%$ & $-18.21 \%$ & $1.93 \%$ \\
23- Valea Rea 4 & 0.36 & 0.35 & 0.32 & $-3.31 \%$ & $-6.85 \%$ & $-9.93 \%$ \\
24- Zanogutele Galeșului 1 & 0.10 & 0.09 & 0.09 & $-5.84 \%$ & $1.38 \%$ & $-4.55 \%$ \\
25- Zanogutele Galeșului 3 & 0.18 & 0.20 & 0.19 & $13.88 \%$ & $-3.75 \%$ & $9.61 \%$ \\
26- Valea Rea 6 & 0.16 & 0.20 & 0.20 & $24.81 \%$ & $0.00 \%$ & $24.81 \%$ \\
27- Lia & & 1.36 & 1.30 & & $-4.26 \%$ & \\
\hline Total Areag $^{\text {20 }}$ & 38.09 & 38.34 & 38.55 & $0.41 \%$ & $0.58 \%$ & $1.00 \%$ \\
\hline
\end{tabular}

a Difficult to define the west shoreline on 1968 and 2007 satellite images because of shallow water.

b South part of this lake is in topographic shadow, making it difficult to define the boundary.

c Shallow water makes definition difficult on the north-northwest side.

d Calculation includes a small circular island in the water.

e Topographic shadow noted on the south corner of the lake in the 1968 Corona satellite image.

f Snow in the 1968 Corona satellite image may alter the outline.

g Total area does not include Lake 27. Percent change does not include Lakes 19, 26, and 27. 
Table 3. Comparison with 1971 field data. The 1971 lake surface area was derived from the sketches presented in Pisota (1971). Field-based decadal changes (1971-1981) were possible using lake surface areas measurements provided in Decei (1981). Apparently both these studies used the same field techniques.

\begin{tabular}{|c|c|c|c|c|c|}
\hline \multirow[t]{2}{*}{ Alpine Lake No. } & \multicolumn{2}{|c|}{$\begin{array}{c}\text { Field } \\
\text { Measurements } \\
\text { (Area in ha) }\end{array}$} & \multirow{2}{*}{$\begin{array}{c}\text { Satellite Data } \\
\text { (Area in ha) } \\
1968 \\
\end{array}$} & \multirow{2}{*}{$\begin{array}{l}\% \text { Change } \\
1971 / 1968 \\
\end{array}$} & \multirow{2}{*}{$\begin{array}{r}\% \text { Change } \\
1981 / 1968 \\
\end{array}$} \\
\hline & 1971 & 1981 & & & \\
\hline 1- Tăul Ştirbuluia & 0.95 & 0.95 & 1.24 & $-22.82 \%$ & $-22.82 \%$ \\
\hline 2- Ana & 3.14 & 3.10 & 3.34 & $-6.08 \%$ & $-7.18 \%$ \\
\hline 3- Bucura & 8.86 & 8.90 & 8.76 & $1.20 \%$ & $1.59 \%$ \\
\hline 4- Tăul Retezatc & 1.00 & & 0.86 & $15.94 \%$ & \\
\hline 5- Tăul Peleagad & 1.73 & 1.70 & 2.24 & $-23.09 \%$ & $-22.76 \%$ \\
\hline 6- Tăul Valea Rea & 0.79 & 0.80 & 0.70 & $11.87 \%$ & $14.28 \%$ \\
\hline 7- Galeșula & 3.68 & 3.70 & 4.11 & $-10.35 \%$ & $-9.97 \%$ \\
\hline 8- Tăul Ţapuluie & 2.28 & 2.30 & 2.34 & $-2.69 \%$ & $-1.70 \%$ \\
\hline 9- Pietricelele & 0.45 & & 0.29 & $52.87 \%$ & \\
\hline 10- Negru & 4.05 & 4.00 & 5.01 & $-19.20 \%$ & $-20.15 \%$ \\
\hline 11- Tăul Judelef & 0.84 & 0.80 & 1.01 & $-17.04 \%$ & $-20.79 \%$ \\
\hline 12- Tăul Gemenele & 2.48 & 2.50 & 2.83 & $-12.31 \%$ & $-11.69 \%$ \\
\hline 13- Tăul Agăţata & 0.11 & 0.10 & 0.09 & $22.63 \%$ & $11.11 \%$ \\
\hline 14- Tăul Porţii & 0.49 & 0.50 & 0.38 & $30.23 \%$ & $31.57 \%$ \\
\hline 15- Florica ${ }^{a}$ & 0.80 & 0.80 & 0.45 & $79.02 \%$ & $79.02 \%$ \\
\hline 16- Viorica & 0.94 & 0.95 & 0.70 & $34.43 \%$ & $35.71 \%$ \\
\hline 17- Tăul Peleguţa & 0.95 & 0.95 & 0.94 & $0.99 \%$ & $0.99 \%$ \\
\hline 18- Tăul Adânc & 0.29 & & 0.40 & $-27.02 \%$ & \\
\hline 19- Tăul Stevia & & 0.7 & 0.58 & & $20.68 \%$ \\
\hline $\begin{array}{l}\text { Total Area/ } \\
\text { Average \%change }\end{array}$ & 33.81 & 32.75 & 36.25 & $6.03 \%$ & $3.57 \%$ \\
\hline
\end{tabular}

a Lake interpretations vary significantly.

$\mathrm{b}$ The interpretation on the northeast side of the lake differs slightly between the field interpretation and the satellite interpretation.

c There are minor differences between how the field interpretation and the satellite interpretation deal with the deltas/shallow areas on the north and south sides of the lake.

${ }^{d}$ There is a significant difference in how a delta on the north side of the lake is outlined in the field and satellite interpretations.

e The east/northeast side of the lake differs significantly between the two interpretations. There also is an island included in the satellite interpretation that may or may not be included in the field interpretation.

$f$ There is a difference in interpretation on the north side where the delta is located.

$g$ There are differences between outlining of small adjacent lakes on the southwest side. The field interpretation does not include this lake, while the satellite one does. There also is a difference in how the deltas are categorized on the north side. 
Table 4. Comparison with 2007 field data. Change calculation excludes the measurement for Viorica Lake, the shallowest lake in the dataset (depth less than $2.15 \mathrm{~m}$ ), which was significantly impacted by the rain events that occurred between August (field measurement) and September 2007 (satellite data acquisition). Field data from Vespremeanu-Stroe et al. (2008).

\begin{tabular}{|l|c|c|c|}
\hline \hline \multirow{2}{*}{ Alpine Lake } & \multicolumn{2}{|c|}{ Lake Area (ha) } & \multirow{2}{*}{} \\
\cline { 2 - 3 } & $\begin{array}{c}\text { Field } \\
\text { Measurements }\end{array}$ & $\begin{array}{c}\text { Satellite Data } \\
\text { Interpretation }\end{array}$ & Change \\
\hline \hline 2- Ana & 3.6172 & 3.585 & $0.89 \%$ \\
3- Bucura & 8.9233 & 9.144 & $-2.47 \%$ \\
7- Galeșul & 4.0375 & 3.944 & $2.32 \%$ \\
13- Tăul Agăţat & 0.096 & 0.094 & $2.34 \%$ \\
14- Tăul Porţii & 0.4412 & 0.431 & $2.26 \%$ \\
15- Florica & 0.5238 & 0.515 & $1.68 \%$ \\
\hline \hline Total change & 17.639 & 17.71 & $-0.42 \%$ \\
\hline \hline
\end{tabular}

